ROCZNIKI NAUK SPOŁECZNYCH

Tom 12(48), numer $3-2020$

DOI: https://doi.org/10.18290/rns20483-4

JERZY NIKOŁAJEW

\title{
ENFORCEMENT OF CUSTODIAL SENTENCE IN THE LIGHT OF WHO GUIDELINES DURING THE COVID-19 PANDEMIC IN POLAND ON THE EXAMPLE OF THE CORRECTIONAL FACILITY IN CHEŁM
}

\section{INTRODUCTION}

The enforcement of the custodial sentence is the responsibility of the state and its implementation is entrusted to specific state institutions. In the Polish legal order, tasks associated with the enforcement of the custodial sentence (including detention on remand) are performed by the Prison Service in accordance with the applicable law. ${ }^{1}$ Proper performance of these tasks is supervised primarily by the Minister of Justice, who not only establishes and abolishes correctional facilities and pre-trial detention centres, but also issues legal acts (regulations and orders) governing in detail the principles for imprisonment and pre-trial detention. $\mathrm{He}$ is authorized to do so directly by the provisions of the Executive Penal Code (hereinafter: the Executive Penal Code). ${ }^{2}$ In addition, the Director General of the Prison Service, as the official superior, is authorized to issue orders applicable to all correctional facilities and pre-trial detention centres in Poland. In turn, district directors of the Prison Service and heads of particular prisons and pre-trial detention centres (each acting in accordance with their local jurisdiction) may issue specific orders related to the situation at a given place and time. All such guidelines and orders must be based on the law, especially when the rights of convicts and those remanded on custody are restricted. The sanitary and epidemiological threat referred to in Article 247 para. 1 of the Executive Penal Code authorizes the head

Prof. JeRZy NiKOŁAJEW - The Institute of Legal Sciences, Faculty of Law and Administration, University of Opole; address for correspondence: ul. Katowicka 87a, 45-060 Opole; e-mail: jnikolajew@uni.opole.pl; ORCID: https://orcid.org/0000-0003-1505-9710.

${ }^{1}$ Act of 09 April 2010 on Prison Service, consolidated version: Journal of Laws of 2020, item 848.

${ }^{2}$ Act of 07 June 1997-Executive Penal Code, consolidated version: Journal of Laws of 2020 , items 523, 569. 
of a prison or a pre-trial detention centre to introduce highly drastic restrictions in the day-to-day functioning of correctional facilities managed by them. This may involve the limitation of contacts inside the prison as well as of the possibility of direct communication between convicts and detainees with the nonprison environment. The introduction of a sanitary regime entails mainly activities that prevent or limit the spread of infectious diseases. The extent of such restrictions most often paralyses normal operation of the prison's internal order for a limited time. To extend the duration of restrictions on the exercise of statutory rights of persons deprived of liberty, a consent of the penitentiary court, which is a body directly supervising the execution of criminal judgments, is required. In simplified terms, the point is that the head of a correctional facility or a pre-trial detention centre, as an executive authority, should be supervised by an independent judicial body and could not abuse its statutory powers that may actually limit the rights provided for under the law.

At the same time, it should be clear that not only official supervisory authorities (the Minister of Justice, the Director General of the Prison Service, district directors of the Prison Service) but also other state authorities, not directly related to the enforcement of isolation sentences, may issue regulations concerning e.g. sanitary and health protection requirements for persons deprived of liberty. The medical and sanitary inspection authorities are also empowered to supervise the sanitary and epidemiological conditions at all correctional facilities and to introduce justified restrictions on the rights and freedoms of convicts and those remand in custody. In addition, in the face of global threats, the World Health Organization (hereinafter: WHO) may issue specific recommendations for combating the epidemic of certain diseases, especially when they pose a threat of pandemic. Therefore, taking into account the nature of correctional facilities and pre-trial detention centres as well as the physical and mental condition of people staying there, already at the outset of the Covid-19 pandemic, WHO issued detailed and extensive guidelines regarding the preparedness, prevention and control of Covid-19 in prisons and other places of detention. ${ }^{3}$ The document dated 15 March 2020 provides an interim guidance (as suggested by its very title). However, it must be emphasized that the guidelines of the WHO Regional Office for Europe should be treated as a precedent, as such recommendations had never been issued before, the reason being that such a risk in places of imprisonment

\footnotetext{
${ }^{3}$ The author used the text of the guidelines published on the website of the Commissioner for Human Rights at: www.rpo.gov.pl/sites/default/foles/Przygotowanie\%2C\%20zapobieganie\%20\% kontrola\%C2\%AOCOVID-19\%20wzakladach\%20karnych/20\%AOmiejscach\%20pozbawienia\%wo lnosci\%20.pdf as accessed on: 31/08/2020].
} 
was marginalized. While it is true that the European Standard Minimum Rules for the Treatment of Prisoners, and earlier the United Nations Standard Minimum Rules for the Treatment of Prisoners, obliged the state authorities to ensure proper medical and sanitary standards in prisons, the risk considered therein was not associated with a pandemic. Although there were threats, mainly local ones, these were related especially to various mutations of influenza or tuberculosis, scabies or other diseases caused by unsanitary living conditions. In case of non-European countries, infectious diseases were also associated with the climatic conditions and low interest of the state authorities in the situation in prisons. Such an approach was characteristic also in Europe in the old days, when the epidemics of cholera, plague and typhus and other infectious diseases spread. However, contemporary approach to the penitentiary system, combined with the necessity for subjective treatment of convicts, helped to develop a health care system for the places of imprisonment and to lay down the protection safeguards. The WHO guidelines of 15 March 2020 should be treated similarly, and although they are temporary, they should be considered as a form of support for this organization in providing health care for persons deprived of liberty and as a practical guidance regarding the preparedness, prevention and control of the coronavirus pandemic in correctional facilities and other places of detention. Nevertheless, these guidelines should be juxtaposed with the reality of Polish prisons based on the practice prevailing at particular facilities. The choice of the Chełm correctional facility is not a coincidence since the author lives in this city and knows the specificity of this prison from his lawyer's practice and contacts with the local prison administration as well as convicts and detainees imprisoned there. ${ }^{4}$

\section{WHO DETAILED RECOMMENDATIONS}

The WHO guidance of 15 March 2020 [...] is a document is based on the latest available evidence on the COVID-19 outbreak as of 15 March 2020. The World Health Organization (WHO) continues to monitor the situation closely for any changes that may affect this interim guidance. Should any factors change, WHO will issue a further update." However, until 31 August 2020 (date of this paper), this guidance has not been updated, despite the changing incidence rates and methods for combating the pandemic in prisons, pre-trial detention centres and other places of detention, which undoubtedly also include

\footnotetext{
${ }^{4}$ This paper takes into account the facts and legal status as of 31 August 2020.
} 
prisons managed by private entities, centres for migrants, detention centres for children and adolescents (in the Polish legal system: juvenile detention centres and shelters for minors). The text of the guidelines has been published on the official website of the WHO Regional Office for Europe in Copenhagen. It should also be emphasized that the document was prepared by a broadly understood community of experts in the field of infectious diseases, people professionally involved in healthcare provided in places of imprisonment, workers and collaborators of the International Red Cross, the United Nations Office for Drugs and Crime, and other experts from Switzerland, France, Finland, the Netherlands, Italy, the United States and Australia. The purpose of the guidelines is to "protect the health and well-being of people detained in prisons and other closed settings, those who work there (custodial, health-care and other staff), and people who visit prisons and other places of detention (legal visitors, family and friends of prisoners etc.)." Other objectives of this document are also to "support the continued safe operation of prisons and other detention settings, and to reduce the risk of outbreaks which could place a considerable demand on health-care services in prisons and in the community." In addition, the guidelines are to "reduce the likelihood that COVID-19 will spread within prisons and other places of detention and from such settings into the community and to ensure the needs of prisons and other detention settings are considered in national and local health and emergency planning." It is rightly noted in the introduction to the guidelines that "people deprived of their liberty, such as people in prisons and other places of detention, are likely to be more vulnerable to the coronavirus disease (COVID-19) outbreak than the general population, because of the confined conditions in which they live together for prolonged periods of time. Moreover, experience shows that prisons, jails and similar settings where people are gathered in close proximity may act as a source of infection, amplification and spread of infectious diseases within and beyond prisons." It was also reasonably stressed that "prison health is therefore widely considered as public health, and the response to COVID-19 in prisons and other places of detention is particularly challenging, requiring a whole-of-government and whole-of-society approach." The authors also justly noted a potential negative effect of restricting the rights and freedoms of prisoners, who are anyway deprived of most of their rights as a result of their imprisonment. Therefore, the WHO points out that "people in prisons and other places of detention are already deprived of their liberty and may react differently to further restrictive measures imposed upon them." Thus, possible restrictions on the rights and freedoms of prisoners as a result of new sanitary and epidemiological regimes should be characterized by the need to avoid 
possible panic or situations threatening general prison security and to ensure an adequate response to the prevailing epidemic threat. Accordingly, the WHO recommends coordination actions based primarily on joint planning of measures by prison administrations and state authorities. They should undertake a risk assessment of all people entering the prison and collect information on any history of cough and/or shortness of breath, patients' recent travel history and possible contact with confirmed cases in the last 14 days. Persons checked should include prisoners/detainees, visitors and prison staff. Prison management staff is responsible for providing "a high level of vigilance and support of their staff." Prison authorities should plan possible visits in such a way as to provide advice on the suspension of visits well in advance and not to expose visitors to unnecessary costs. On the other hand, where visits are allowed, the guidelines recommend the introduction of a special authorization procedure including, for example, maintenance of a detailed daily registry of people moving in and out of the prison. It is also recommended to consider measures alternative to visits, providing the convicts and detainees with the opportunity for family contacts, by increasing the frequency of phone or Skype calls. The psychological impact of these measures needs to be considered and mitigated as much as possible, and basic emotional and practical support for affected people in prison should be available.

As a rule, a 14-day quarantine is recommended, which shall be understood as a strategy for limiting the effects of infections through on-site isolation e.g. in a prison or another place of detention. In addition, prison health-care staff are recommended to use personal protective equipment (masks, gloves, aprons) as well as to observe the air exchange rules, routine (daily) disinfection of rooms and the so-called physical distancing during the possible but limited movement of convicts outside their cells. At the same time, the document suggests the need for ensuring a minimum period of prisoners' access to the open air, which should not fall below a minimum of one hour per day. Thus, it acknowledges the necessity to observe the law providing for the right to leave the cell for a specified period of time during each day of imprisonment for the purpose of physical relaxation and rest.

The WHO guidance presents also the Covid-19 virus pathogen characteristics, signs and symptoms as well as describes how the virus is transmitted. This information is intended mainly for the prison health-care staff to help them deal with the effects of the pandemic. It also has a practical value, as it recommends the use of disinfectors alternative to alcohol-based disinfectants, so as to avoid undesirable consequences such as lower level of security in prisons. Therefore, 
the authors suggest the use of non-alcoholic disinfectants such as chlorine-based gels used under the supervision of the managers of prisons and other places of detention.

According to WHO guidelines, a key element of any preparedness plan for prisons and other places of detention is the training of staff covering basic disease knowledge, including pathogen, transmission route, signs and clinical disease progression, hygiene practice and respiratory etiquette as well as appropriate use of hygiene measures, including cleaning and disinfection agents. Therefore, the WHO proposed the use of its materials in the form of online training on personal protective equipment and clinical management of severe acute respiratory infection (SARI), risk information packets (slogans, messages) and technical guidance (e.g. advice on use of masks).

At the same time, the WHO recommends a consistent and coordinated action to provide inmates, visitors, prison staff and healthcare professionals with information on the risks associated with the current pandemic. Information materials (short brochures, leaflets, posters) should include, inter alia, local risk assessment, including that of a specific correctional facility, advice on the use of measures in the event of disease symptoms, information on symptoms and signs of disease, advice on self-monitoring and access to medical care.

A separate package of WHO recommendations covers terminological issues related to the definition of such terms as suspected case, probable case, contact as well as the details of the Covid-19 case reporting procedure. The above-mentioned recommendations are addressed to prison and non-prison health-care staff and are intended to limit the effects of the disease in the environment of prisons or other places of detention.

The authors of the recommendations, being aware of the lack of a vaccine to prevent Covid-19, rightly suggested the need for development and implementation of a preventive system involving e.g. frequent washing of hands, use of disposable towels, maintaining an appropriate physical distance, covering the mouth and nose when coughing or sneezing, avoiding touching the nose or mouth with dirty hands. Thus, prison administrations are required to install safe wall-mounted liquid soap dispensers, paper towels and foot-operated pedal bins i.e. equipment not previously provided in most prisons. There are separate standards for use of medical masks so as to ensure their maximum effectiveness and avoid increasing the risk of virus transmission due to the inappropriate use of masks. In general, the use of masks made of cotton or gauze is strongly discouraged and there are recommendations in place for the use of masks in a strictly defined way (putting on, taking off, disposal after use). 
The prison authorities are required to use appropriate procedures for environmental cleaning and disinfection, washing linen, bedclothes and towels, handling infectious waste and maintaining distance during medical contacts. It is also recommended that appropriate prison premises be designated for epidemiological quarantine purposes and that prison staff should use masks and gloves when performing their official duties. The obligation to use personal protective equipment is also extended to all other persons entering the prison and other places of detentions, who are also required to have their body temperature checked.

The guidance relevant for the penalty of deprivation of liberty is included in section 12.5 of the document of 15 March 2020, as it provides for consideration of access restriction and movement limitation. The management of prisons and other places of detention are suggested to provide an assessment of each facility and its setting for the current epidemiological threat. The advice developed in conjunction with the local public health agency may provide for a temporary suspension of on-site prison visits, but needs to be "carefully considered in line with local risk assessments." The guidelines point to the need for mitigation of negative impact of such restrictions on inmates e.g. the ones associated with the limited contact with children. Measures that may be considered include, as appropriate, restriction of family visits, reducing visitor numbers and/or duration and frequency of visits, and introduction of video conferencing for family members and representatives of the judicial system, such as legal advisers. The guidelines even provided for detailed solutions such as screening at entrance with self-reporting questionnaire to exclude those with symptoms. Notwithstanding the foregoing, a workplace protocol for how to manage such situations, including a suspected or confirmed COVID-19 case or their contacts, is recommended for each prison or another place of detention.

The document provides separate guidance on the use of personal protective equipment and other standard precautions by health-care and prison staff who come into contact with patients diagnosed with Covid-19. First of all, attention was paid to the need for them to undergo training in standard precautions, the use of gloves and protective masks, maintaining an appropriate distance, safe handling of waste, bedclothes, and sterilization of equipment used in patient care. It is also recommended that health-care staff should use the so-called full gown, respirator masks, clinical waste bags, virucidal detergents and disinfectants. All staff should apply the so-called "five moments for hand hygiene" approach to cleaning their hands i.e. before touching a patient, before any clean or aseptic procedure is performed, after exposure to body fluid, after touching a patient, and after touching a patient's surroundings. In turn, custodial/detention staff 
returning to work following travel to affected areas or with a history of potential exposure should consult occupational health services and prisons should review their continuity and contingency plans and update them to ensure that they can perform critical functions with reduced numbers of personnel.

The WHO guidelines also refer to people discharged from prisons and other places of detention, stipulating that if a person who has served their sentence is an active COVID-19 case at the time of their release, or is the contact of a COVID-19 case and still within their 14-day quarantine period, such a person must continue the quarantine after having been discharged. The prison health authorities are obliged to ensure that the person discharged has a place to go where they can maintain quarantine, and that the local authority is notified that the person discharged is to continue the quarantine. At the same time, it was ordered to provide complete medical documentation concerning such a patient, together with an indication of the person's COVID-19 status (confirmed or suspected).

\section{PRACTICAL MEASURES TAKEN IN THE COMBAT AGAINST COVID-19 IN PRISONS IN POLAND AND ABROAD}

Already at the outset of the pandemic, the Central Board of Prison Service issued regulations on the coordination of actions related to epidemiological threats in prisons and pre-trial detention centres. Order No. 20/20 of the Director General of the Prison Service of 2 March 2020 on the appointment of a team to coordinate actions taken in connection with the epidemiological threat in organizational units of the Prison Service provides that the duties of the said team include coordinating and supervising activities of the prison headquarters related to the threat (occurring in prisons and pre-trial detention centres) as well as reporting to the Director General of the Prison Service on the status of the threat at individual subordinate organizational units. Members of the team include ex officio all the heads of offices of the Central Board of the Prison Service; however, the effects of their involvement cannot be considered commensurate with social expectations. The responsibility for the current epidemiological status of prisons and detention centres lies with their directors, as pointed out by the Commissioner for Human Rights in Letter No. IX.517.664.2020 MK of 3 April 2020, who directly asked the Director General of the Prison Service about actions taken (possible guidelines, ordinances, procedures), but did not receive an answer. Earlier (in March 2020), the Director General of the Prison Service issued recommendations for the restrictions on the existing rules of imprisonment and 
in the Letter of 11 March 2020, ordered non-contact measurements of body temperature of all persons entering prisons and pre-trial detention centres (this obligation also applies to prison officers). In the same letter, the Director General recommended considering increasing the frequency and duration of telephone calls and contacts with the family ones through social messaging platforms. At the same time, the functioning of classes in prison schools has been suspended, as identical solutions have been introduced for schools operating outside prisons. In turn, in the Letter of 31 March 2020 (BIS.400.13.2020), the Director General of the Prison Service ordered to limit as far as necessary the transport of prisoners and to provide transport only when it is considered fully justified.

The measures undertaken by the prison authorities cannot be considered sufficient. On the other hand, however, in other European and non-European countries, the responsibility for the decisions taken has been delegated to the lowest organizational level i.e. heads of prisons and pre-trial detention centres. According to Prison Insider, the similarities in the adopted solutions for combating Covid-19 in prisons, regardless of the penitentiary policy implemented, included (at least at the beginning of the pandemic) introducing restrictions on or prohibiting visits, releasing prisoners (temporarily or permanently) from serving the remainder of the sentence, more frequent use of house arrest or electronic monitoring, postponement of punishment and activating prisoners to sew masks and protective clothing. ${ }^{5}$

For example, in Italy, visits to prisons were completely banned on 08 March 2020. As a consequence, this led to an escalation of tensions and the outbreak of protests in several dozen prisons, including in Modena, Milan, Rebibbia, Foggia, while at the same time it was decided to use the formula of house arrests more widely instead of the usual imprisonment in overcrowded cells. In turn, in Ukraine, on 11 March 2020, a nationwide quarantine was announced, which in prison practice translated into the introduction of a prohibition of visits, the need for daily measuring of body temperature of prisoners and prison staff, disinfection of correspondence, letters and parcels, and disinfection of cells and prison canteens every three hours. Transport of convicts was limited to the necessary minimum, except for the medically justified cases. Contacts between convicts were allowed only between inmates imprisoned in the same cell and

\footnotetext{
${ }^{5}$ A majority of Polish prisons and pre-trial detention centres conducted social campaigns, where the inmates sew protective masks to be distributed to social care homes, orphanages or hospitals operating outside the prisons. Some of these initiatives came from the inmates themselves and were not inspired by the prison staff.
} 
all those commencing imprisonment were quarantined for a period of 3 weeks. In addition, the sessions of the penitentiary court were held in the form of video conferences, and from 27 April 2020, unfinished legislative works on the amnesty law continued, so that convicts with serious health problems, the elderly and disabled, and those caring for minor children could use that law.

On the other hand, on 3 March 2020, the Iranian authorities allowed for early discharge from prison for those have been tested negative for coronavirus, but only after having paid an appropriate bail. This category of prisoners excludes those sentenced to more than 5 years of imprisonment and those sentenced for crimes against the state and public security as well as foreigners. Such decisions, which categorized prisoners, caused riots in many Iranian prisons, inspired mainly by those inmates, who did not enjoy the benefits of the relaxed penitentiary policy. Riots in the Iranian prisons were also caused by the lack of adequate protection against the virus and the fear of infection by inmates.

Like Iran, the Turkish government adopted solutions providing for discharge of certain categories of convicts as early as on 14 April 2020. The "privileged" group included convicts who have reached 65 years of age, women with children up to six years of age, and prisoners requiring care. The formula for use of house arrest and obtaining conditional early discharge has also been extended. However, sex offenders, drug offenders, first-degree killers, and perpetrators of violence against women and terrorist offences are not allowed to take advantage of this solution. ${ }^{6}$

On the other hand, the risk of the pandemic in the United States was much greater than elsewhere. This stems from objective difficulties such as the enormous population of people in detention (about 2 million people placed in about six thousand correctional facilities), the annual rate of admissions to prisons (ca. 5 million people) and the high mortality rate of convicts infected with the virus (approx. 800 people for whom the Covid-19 was entered as the cause of the death in the death certificate). Therefore, already at the outset of the pandemic, the federal authorities decided to issue guidelines for combating the disease, but these included only the guidance for prison officers. The Centers for Disease Control and Prevention, operating within the structures of the U.S. Department of Health and Human Services, decided that state authorities should make their own decisions in the fight against the pandemic, and that the directorates of all prisons (both federal and state) should develop an appropriate strategy for dealing with coronavirus patients. Thus, since April 2020,

\footnotetext{
${ }^{6}$ See A. PorĘBSKA, Co wirus zmienit w więzieniach [What has the virus changed in prisons], "Forum Służby Więziennej” 7 (2020), pp. 30-31.
} 
a temporary program has been implemented in Pennsylvania prisons to reprieve sentences of incarceration until the epidemic stops. At the same time, new convicts do not start serving their sentence and stay at home until they are called upon to serve the sentence in safe prison conditions. This solution has the characteristics of an institution that is well known and often used in the criminal law of many countries worldwide as "deferment of sentence" (except that it is used ex officio, and not at the party's request). On the other hand, in those American prisons, where the imprisonment sentence is enforced in a traditional way, new entrants are tested for the virus already on admission to the prison. Prisoners can also benefit from medical care using phone consultation. In order to reduce the concentration of prisoners in one place and time, meals are served at different times. Convicts are also allowed to have more frequent phones contacts as a way to compensate for suspended visits. However, unrest in prisons was not avoided and, for example, in one of the correctional facilities in New Mexico, cells were barricaded and burned, as the prisoners demanded more Covid-19 tests. ${ }^{7}$

\section{CASE OF THE CORRECTIONAL FACILITY IN CHEŁM}

On 11 April 2020, at the time when Holy Saturday was celebrated in the Catholic Church, nearly 80 inmates of prison in the Chełm refused to accept breakfast. Such behaviour of inmates (on that day a total of 658 prisoners and remand prisoners were kept in the prison for recidivists in Chełm) was classified as collective disobedience and procedures related to restoring order in the prison were launched. In accordance with the emergency procedure, all local officers of the Prison Service and the so-called Intervention Group of the Prison Service from Lublin, whose task is to restore order by force in the event of a threat to the security of the prison, were called upon. As a result of talks conducted by educators, the director of the prison and his senior superiors, some inmates accepted lunch and all prisoners had dinner. ${ }^{8}$

As it turned out later, the hunger strike at the prison in Chełm was the only act of collective disobedience in Poland in connection with the restrictions on the rights of prisoners introduced in connection with the fight against the 2020

\footnotetext{
${ }^{7}$ See A. PORĘBSKA, Co wirus zmienit $w$ więzieniach (2) [What has the virus changed in prisons], "Forum Służby Więziennej" 2020, no. 8, pp. 30-31.

${ }^{8}$ Bunt $w$ więzieniu $w$ Chetmie. Powodem sa wprowadzone ograniczenia zwiazane z epidemia, [Riot in the prison in Chetm due to epidemic-related restrictions], "Dziennik Wschodni" of 14 April 2020, pp. 4-5.
} 
pandemic. Protesting prisoners even managed to put the so-called the convicts' manifesto in the form of 12 demands. Further, (which is not without significance) there was a protest against the presidential election planned for 10 May 2020, followed by a proposal to postpone the election until the end of the epidemic. There was also demand to introduce the so-called penitentiary year (without clarifying the essence of this postulate), suspension of transports, improvement of sanitary and social conditions in cells (hot water, baths in residential departments, increasing the size of cells), making the prison gym available, increasing the availability of telephones as an alternative to the suspended visits. The demands included also free access to Skype on Wednesdays and Saturdays, the restoration of the right to receive the so-called hygiene packages, increasing the weight of food packages, improving the quality of meals, access to hygiene and medical care, as "they do not measure anyone's body temperature." At the end of the protest letter, its authors (signed as "Chełm Prison People") also issued the following statement: "We will strive to ensure that our demands are fulfilled and we call upon all people to join us, because, as we know, it is better to die standing than to live on our knees. Our hearts and minds are with the doctors and medical staff, who are fighting it, as well as with all the sick who suffer and, of course, with our loved ones. Each of us prays in our own way for the epidemic to end as soon as possible and also for recovery." "9

The fact that the prisoners' statements appeared in the virtual space was not commented on by the press services of the prison system at any organizational level. The only information about the earlier and subsequent decisions made by the management of the Prison in Chełm in connection with the epidemic was published on the prison's website. It showed that until 11 April 2020, four orders regulating the above limitations were issued. From 12 March 2020, the obligation to measure body temperature was introduced for all (inmates and staff), and from 19 March 2020, visiting prisoners was prohibited. Starting from 23 March 2020, the convicts' rights to maintain contacts with their relatives were extended in such a way that they were allowed to contact them via instant messaging or telephones, and families were provided with orders for parcels by e-mail. On 6 April 2020, the director of the prison in Chełm issued a new order prohibiting prison furloughs and visits or work outside the prison, and ordered the prison staff to perform their official duties only in protective masks. After 11 April 2020, the director of the prison, acting all the time pursuant to the statutory authorization under Article 247 para. 1 of the Executive

\footnotetext{
${ }^{9}$ The text of the protest letter was published in the local newspaper. See Bunt $w$ chetmskim więzieniu, [Riot in the prison in Chetm], "Super Tydzień Chełmski" of 17 April 2020, pp. 2-3.
} 
Penal Code, issued further orders (in each case for the next 14 days) limiting the prisoners' rights to visits, external employment, furlough and religious services. It was only in July 2020 that there was a clear (but not yet complete) liberalization in this area and a gradual restoration of at least some of the prisoners' rights. Therefore, effective from 24 July 2020, the visitor policy was modified, and accordingly, only one (adult) person could participate in the visit (thus preventing contact with children before they turn 18). In addition, maximum one-hour visits were held on individually agreed days and times (these were agreed by phone or via the facility's e-mail). At the same time, the limit of applications for visits on a given day was set, while the persons declaring their willingness to attend a visit were obliged to appear half an hour in advance. Visitors were divided into groups of ten. They were required to have their body temperature measured and to use protective masks, gloves and disinfectants, as well as to deposit all their personal belongings. There was also a ban on physical contact between the visitors and the inmates and a two-meter distance between them. During the visits, the prison canteen (which had been previously used to make joint purchases) was closed, and after each visit, the stands and toilets were disinfected, whereas the used masks and gloves were disposed of into special containers.

According to the announcement of the prison director of 29 July 2020, effective from 2 August 2020, the external employment of inmates was further suspended for a period of 14 days, except that those working at the production hall or performing cleaning works in the area adjacent to the prison, just like holding religious services or receiving parcels. The announcement reconfirmed the previously introduced visitor policy, while indicating that the convicts were entitled to one visit per month, regardless of the type of prison in which they are serving their sentence of imprisonment. In the introduction to the announcement, it was emphasized that these measures were taken "in connection with the occurrence of confirmed cases of SARS-COV-2 in the Lubelskie Voivodeship and taking into consideration the recommendations issued by the State Sanitary Inspector." However, the said recommendations were not specified in detail and it was not clarified that the restrictions on the prisoners' rights were introduced pursuant to an order of the prison director (announcements are only a form of publication for the orders).

At the same time, it should be noted that other rights of convicts at the prison in Chełm such as the right to a court hearing at the stage of enforcement proceedings (regarding conditional release, interval in serving a sentence, complaint to a penitentiary court) during the pandemic, may be enforced online, as provided 
for in the ministerial guidelines. Therefore, court hearings are not scheduled on the prison premises, which used to be the rule), but are held online with the participation of all parties to such proceedings. Hitherto, the convicts have not complained about this way of organizing the work of the penitentiary court, as their procedural rights have not been limited in any way. ${ }^{10}$

\section{CONCLUSION}

In accordance with the provisions of Article 247 para. 1 of the Executive Penal Code, in particularly justified cases e.g. due to sanitary or health concerns, the director of a prison or pre-trial detention centre may, for a specified period (7 days), introduce temporary restrictions or prohibitions regarding the exercise of rights of convicts or remand prisoners (a longer period requires the approval of a penitentiary judge). This legal provision implies that it is possible to suspend or limit the employment of inmates, contacts between them, visits and walks, collective activities, holding and provision of religious services, shopping, receiving parcels, and payphones. Prison directors may also, for the same reasons, order the closure of cells or other rooms intended for stay or work of prisoners, and prohibit them to have certain items in cells, or suspend the function of a spokesman for prisoners. After the outbreak of the Covid-19 epidemic in March 2020, most Polish prisons and pre-trial detention centres introduced restrictions, which primarily included the prohibition of visits and external contacts with prisoners (prison furlough, visits and employment outside the prison). Especially the restrictions on visits and the five-month suspension period (March-August) caused understandable dissatisfaction, in particular, among those inmates who previously had regular visits with their families, especially children. As a consequence, there were riots in some prisons in Poland and abroad (e.g. hunger strike in Chełm was caused directly by the restrictions imposed by the prison authorities in the fight against the pandemic). The solutions introduced to mitigate the effects of increased isolation of inmates and more frequent telephone contacts or use of Skype were to compensate for the restrictions applied. The gradual reintroduction of the possibility of visits for the

\footnotetext{
${ }^{10}$ Such a practice followed the penitentiary court competent for the Prison in Chełm is indeed a new solution adopted as a result of the necessity related to the Covid-19 virus. However, such a practice was used in other prisons before. For example, in the Prison in Piotrków Trybunalski, as early as in 2010, online connections were established for holding court hearings of cases concerning war crimes committed in the former Yugoslavia and tried by the International Criminal Court. See Wokanda na odległość, [Hearing at a distance], "Forum Służby Więziennej” 2020, no. 6, pp. 36-37.
} 
prisoners cannot be recognized as the full exercise of the convicts' rights to contacts with their relatives due to quantitative nature of these restrictions (once per month) without regard to the type of the correctional facility, and bearing in mind the prohibition of the contacts with minor children. Moreover, the adopted restrictions resulted in the extension of the scope of the prison staff's duties, which hitherto had not been performed in prison conditions. Additionally, the needs related to the purchase of personal protective equipment and disinfectants increased. It turned out possible for the prison staff in Poland to acquire these new experiences in extreme conditions thanks to proper reception of the WHO guidelines issued in connection with the outbreak of the Covid-19 pandemic. The WHO's guidance of 15 March 2020 on the preparedness, prevention and control of COVID-19 in prisons and other places of detention (despite their interim nature) has been directly implemented, at least as far as the restriction of access and movement of persons in these places has been concerned. The principles recommended in the guidance providing for the procedure to be followed in the case of Covid-19 confirmation are presented in a fairly detailed fashion and as such could be particularly useful in Polish prisons (especially when it comes to health-care staff), since they quite accurately clarify such issues as pathogen characteristics, Covid-19 symptoms, methods of transmission, virus survival on surfaces, reporting cases of severe acute respiratory infection, clinical management of these cases, or procedures for cleaning and disinfection of premises. Furthermore, the guidelines are addressed to all prison staff as regards the use of personal protective equipment in the performance of their duties. It is even more significant, as the national prison authorities have not issued their own guidelines in this respect, probably supposing (although unjustifiably) that the WHO guidelines would be sufficient. Therefore, decisions (in the form of internal orders) were made at the level of individual prisons and pre-trial detention centres, taking into consideration the rapidly evolving local epidemiological situation.

\section{BIBLIOGRAFIA}

ŹRÓDŁA PRAWA

Ustawa z dnia 7 czerwca 1997 r. - Kodeks karny wykonawczy, tekst jednolity, Dz. U. z 2020 r., poz. 523,569 .

Ustawa z dnia 9 kwietnia 2010 r. o Służbie Więziennej, tekst jednolity, Dz. U. z 2020 r., poz. 848. 


\title{
LITERATURA
}

Bunt w chetmskim więzieniu, "Super Tydzień Chełmski” z 17 kwietnia 2020 r., pp. 2-3.

Bunt $w$ więzieniu $w$ Chetmie. Powodem sq wprowadzone ograniczenia zwiazane z epidemia, „Dziennik Wschodni” z 14 kwietnia 2020 r., pp. 4-5.

PORĘBSKA A., Co wirus zmienit w więzieniach, "Forum Służby Więziennej” 2020, no. 7, pp. 30-31. PORĘBSKA A., Co wirus zmienit w więzieniach (2), "Forum Służby Więziennej” 2020, no. 8, pp. 30-31. System na każdy czas, rozmowa I. Fedorowicz z P. Nasiłowskim, "Forum Służby Więziennej" 2020, no. 9, pp. 12-13.

Wokanda na odległość, "Forum Służby Więziennej” 2020, no. 6, pp. 36-37.

\section{NETOGRAFIA}

www.rpo.gov.pl/sites/default/foles/Przygotowanie $\% 2 \mathrm{C} \% 20$ zapobieganie $\% 20 \%$ kontrola\%C2\%AOC

OVID-19\%20wzakladach\%20karnych/20\%AOmiejscach\%20pozbawienia\%wolnosci\%20.pdf

www.sw.gov.pl/strona/medycyna-pracy-i-bhp-akty-prawne

\author{
ENFORCEMENT OF CUSTODIAL SENTENCE \\ IN THE LIGHT OF WHO GUIDELINES DURING THE COVID-19 PANDEMIC \\ IN POLAND ON THE EXAMPLE \\ OF THE CORRECTIONAL FACILITY IN CHEŁM
}

Summary

During the Covid-19 pandemic, most of the rights of prisoners were clearly limited. These restrictions temporarily affected, among others, visits, out-of-prison employment, prison furloughs and access to religious services. The introduced restrictions significantly increased dissatisfaction among prisoners, which manifested in prison riots in Poland (e.g. in Chełm) and abroad. It should be noted, however, that the full exercise of all the rights and freedoms of prisoners in the conditions of pandemic is not possible, even if compliance with the WHO guidelines set out in the document of 15 March 2020 is ensured. These guidance has been followed rightfully in practice by most Polish prisons and pre-trial detention centres and there have been no reports of serious coronavirus disease outbreaks.

Keywords: epidemiological threat; Covid-19; WHO guidance; imprisonment; restrictions on the rights and freedoms of prisoners.

\section{WYTYCZNE WHO A WYKONYWANIE KARY POZBAWIENIA WOLNOŚCI \\ W CZASIE PANDEMII COVID-19 W POLSCE NA PRZYKŁADZIE ZAKŁADU KARNEGO W CHEŁMIE}

\section{Streszczenie}

W czasie obowiązywania pandemii Covid-19 większość uprawnień skazanych odbywających karę pozbawienia wolności zostało wyraźnie ograniczonych. Obostrzenia dotyczyły m.in. okresowego 
wstrzymania widzeń, zatrudnienia poza więzieniem i udzielania przepustek oraz dostępności do posług religijnych. Wprowadzone ograniczenia zdecydowanie wpłynęły na wzrost niezadowolenia wśród osadzonych, wyrażającego się w formie buntów więziennych w Polsce (np. w Chełmie) i zakładach karnych za granicą. Jednak należy zauważyć, że pełna realizacja wszystkich praw i wolności skazanych w warunkach pandemicznych nie jest możliwa mimo przestrzegania wytycznych WHO zawartych w dokumencie z 15 marca 2020 r. Wytyczne te w większości zostały prawidłowo wykorzystane w praktyce więziennej polskich zakładów karnych i aresztów śledczych i nie zanotowano w nich występowania poważnych ognisk choroby wywołanej koronawirusem.

Słowa kluczowe: zagrożenie epidemiologiczne; Covid-19; wytyczne WHO; wykonywanie kary pozbawienia wolności; ograniczanie praw i wolności skazanych. 